\title{
A Study on Physico-Chemical Properties of Uthukuli Ghee
}

\author{
S. Bhavani Ramya ${ }^{1}$, D. Baskaran ${ }^{2}$, K. Vijayarani $^{3}$, R. Palanidorai ${ }^{4}$ and D. Ramasamy $^{5}$ \\ ${ }^{1}$ College of Food and Dairy Technology, College of Food and Dairy Technology (TANUVAS), \\ Koduveli, Chennai- 52, India \\ ${ }^{2}$ Department of Livestock Technology (Dairy Science), ${ }^{3}$ Department of Animal Biotechnology, \\ ${ }^{4}$ Department of Livestock Technology (Dairy Science), MVC, Chennai- 52, India \\ ${ }^{5}$ Directorate of Extension Education, MMC, Koduveli, Chennai- 52, India \\ *Corresponding author
}

\section{A B S T R A C T}

\begin{abstract}
Keywords
Ghee, Geographical nature, Physicochemical properties, Nutritional composition

Article Info

Accepted:

15 March 2019

Available Online:

10 April 2019

Ghee is known as valuable natural source of food that has numerous health benefits entirely beneficial to the human population. It is one of the popular ingredients in the Indian diet and takes infinitely prevalent position in the dairy industry market. The geographical production makes curious difference in the physico-chemical properties, flavour uniqueness, sensory and storage stability parameters. Concentrating on the geographically important ghee, uthukuli ghee from region of TamilNadu is known for its extraordinary flavour. Exclusiveness in ghee production is primarily dependent on the area of production, breed of animal, feed used for the animals, temperature and other intrinsic, extrinsic factors. In this paper, physico-chemical parameters such as Reichert- Meissl (Rm) value, Polenske value, Iodine value, Saponification value (SV), Butyro-refractometer (BR) reading, Melting Point, Free fatty acid (FFA), peroxide value, Critical Temperature of Dissolution (CTD) have been determined for geographically relevant uthukuli ghee.
\end{abstract}

\section{Introduction}

'Ghee' the popularly known constantly focused dairy product that showcases predominant health concerns and has basic etiquette in Indian culinary. It has its own auspicious nature right from its antique origin and is generally utilized for numerous occasions. Geographical reputation of ghee differs varyingly from Uthukuli ghee originating from the region of TamilNadu which is recognized as flavorfully prevalent and is of common interest to the consumers.
The production statistics of the ghee is restricted to that area and it has its own remarkable market in the dairy industry. Depending on the various parameters and naturally dependent factors the quality criteria changes are developed in ghee. Denoting the differing qualitative and quantitative changes in ghee produced in Uthukuli in comparison with customarily existing ghee, the primary variations rely on geographical indication. Researchers focus on the production status and other factors for the flavour development in ghee but relating the geographical 
indication in completely innovative sense of work. Mostly the physico-chemical parameters vary with the environmental factors but the flavour profile analysis has not been widely concentrated in relation to the topographically relevant ghee. Insisting that flavour profile also adds exhaustive knowledge in production criteria of the product. Innovative product research is trending and demand for healthy reserves is of wide interest to the consumers.

Ghee making undergoes different methods either from cow or buffalo milk or mixed milk by clarifying the butter and melting the butter to form ghee. Evaporating butter or cream produces ghee imparting flavour. The origin of flavour production starts from the fermentation of microorganism. The methodical concerns and the physicochemical properties have been recorded in the vedas and Indian epics. Concentrating the milk or cream separation process is carried out in making ghee. Ghee in its nature has low moisture content and antioxidant properties, it's preferably shelf stable. It contains high amount of conjugated linolenic acid and good fatty acids. Several standards were developed to regularize the quality characteristics. According to standards, ghee should have minimum of $96 \%$ of fat, $0.3 \%$ maximum moisture, $0.3 \%$ maximum FFA (as oleic acid), peroxide value less than $1 \%$.

Flow Diagram for Making of Ghee

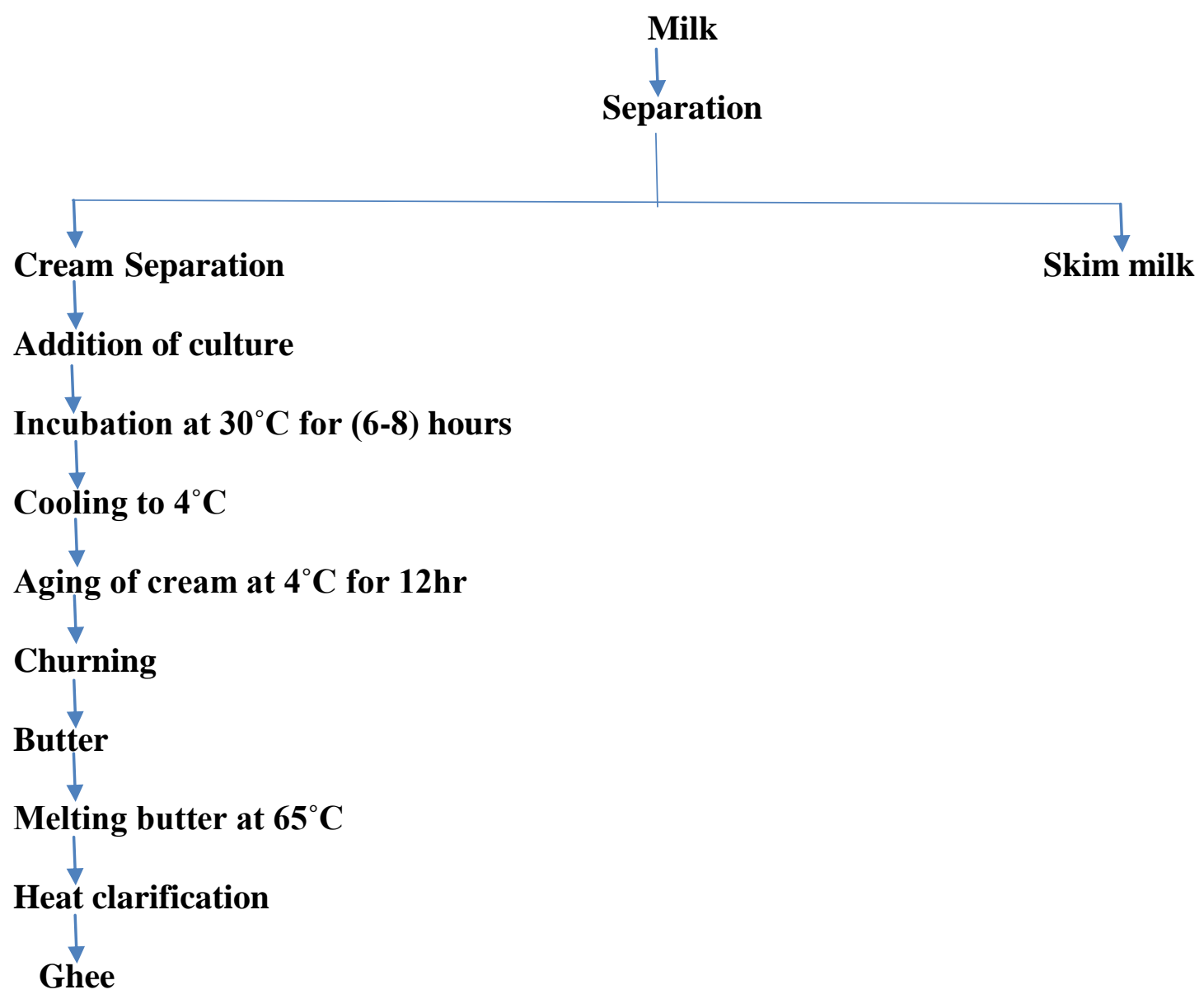




\section{Ghee preparation}

An investigation on physico-chemical properties of ghee produced in Uthukuli in comparison with customarily existing ghee, was studied in the present research. In India, considerable amount of ghee is prepared at home by various methods using milk as the raw material. For this, initially different methods have been standardized for ghee production that are Desi method, Direct cream method, creamery butter method, prestratification method and continuous method. Among these for large scale industrial production pre-stratification method is followed and among the small-scale entrepreneur's desi method and direct milk butter process was preferred. The effective fermentation of cream that allegedly creates extraordinary flavour in ghee. Hence with few modifications of fermenting cream and aging the cream was added in the method of preparation of ghee. The available resources such as feed, water, environmental conditions and animal species are also important factor that contributes to the quality of the ghee.

\section{Methods of analysis}

The physico-chemical properties of geographically relevant uthukuli ghee was studied for ghee prepared by various method. The details of the procedures for various physico-chemical constants are as follows:

\section{Moisture estimation}

The moisture content of the ghee samples was determined by AOAC method. Briefly, $5 \mathrm{~g}$ of the ghee was taken in previously dried and weighed over dishes.

The sample was dried in a hot air oven (Jiotech, South Korea) at $105^{\circ} \mathrm{C}$ for $8 \mathrm{~h}$ till a constant weight was attained. The final weight of the dish containing the sample was measured both before and after drying and moisture content was calculated.
Moisture Content $(\%)=\frac{W 1-W 2}{W 1} \times 100$

Where,

W1 is the weight of the sample with the dish before drying;

W2 is the final weight of the sample with dish after drying.

\section{Crude fat content}

Crude fat was estimated in raw materials and extruded product using the standard extraction method (AOAC) (Anon, 2000) employing Soxtron fat extractor (Tulin equipment, Chennai). The crude fat in the sample and expressed as percent crude fat:

Crude fat $(\%)=\frac{100\left(W_{2}-W_{1}\right)}{S}$

Where,

$\mathrm{W}_{1}=$ Weight of empty beaker $(\mathrm{g})$

$\mathrm{W}_{2}=$ Weight of beaker and extracted fat after drying $(\mathrm{g})$

$\mathrm{S}=$ Weight of sample $(\mathrm{g})$

\section{Crude protein content}

The protein content of the sample was determined by Kjeldahl method using Kjeltron protein analyzer as described in AOAC (Anon, 2003). The total nitrogen and percent protein were calculated as follows:

Nitrogen $(\%)=\frac{14 \times(X-Y) \times \text { Normality of HCl } \times \text { dilution factor } \times 100}{1000 \times \text { Weight of sample }}$

Where,

$\mathrm{X}=$ Volume of $\mathrm{HCl}$ required for sample $(\mathrm{ml})$

$\mathrm{Y}=$ Volume of $\mathrm{HCl}$ required for blank $(\mathrm{ml})$

\section{Protein $(\%)=$ Percent nitrogen $\times$ Conversion Factor}

\section{Cholesterol content in ghee}

Using direct colorimetric method the cholesterol content in ghee samples was 
determined. The method followed as per the method followed by the Bindal and Jain (1973). Measure 0.2g of sample and dissolve in $3 \mathrm{ml}$ of chloroform using standard joint test tube, then added a $4 \mathrm{ml}$ of Liebermann Burchard reagent which contains $1 \mathrm{ml}$ of sulphuric acid in $20 \mathrm{ml}$ of acetic anhydride both in chilled condition and kept for 27 minutes at $0^{\circ} \mathrm{C}$. The entire mixture was allowed to stand for 12 minutes at $250{ }^{\circ} \mathrm{C}$. Optical density for each sample is measured at a wavelength of $650 \mathrm{~nm}$ within 3 minutes. Blank value was also noted and the cholesterol content in sample was calculated with the help of standard curve, prepared using the standard solutions of pure cholesterol

\section{Determination of tocopherol}

Tocopherol content of the ghee sample was determined by Emmerie-Engel method as described in SP:18 (1981). The extracted dry unsaponifiable matter was dissolved in $5.0 \mathrm{ml}$ of benzene and passed through floridin, benzene was distilled under reduced pressure and the residue was dissolved in $10 \mathrm{ml}$ of ethyl alcohol. For the spectrometer reading the sample is prepared by dissolving $5 \mathrm{ml}$ of the residue solution in $1 \mathrm{ml}$ of $0.2 \%$ solution of ferric chloride in absolute ethyl alcohol and $1 \mathrm{ml}$ of $0.5 \%$ solution of $\alpha, \alpha^{\prime}-$ di-pyridyl in absolute ethyl alcohol were added and mixed each time. At $530 \mathrm{~nm}$ wavelength the reading was taken, using the standard curve the tocopherol content of the sample was estimated.

\section{Determination of carotene}

The carotene content of ghee sample was determined by Carr-Price reaction as described in SP:18 (1981). The 5g sample was saponified by refluxing with $50 \mathrm{ml}$ of ethyl alcohol and $7 \mathrm{ml}$ of 50 per cent (w/v) potassium hydroxide solution for 30 minutes. The contents were separated by adding $150 \mathrm{ml}$ of distilled water. Peroxide-free diethyl $(50 \mathrm{ml})$ ether was used thrice to extract unsaponifiable matter and then washed with water to make it alkali-free. The ether present in the extract is evaporated by initially drying over sodium sulphate (anhydrous)and then evaporated on a water bath under reduced pressure. The residue left after evaporation of ether was dissolved in $5 \mathrm{ml}$ of chloroform. After subsequent dissolution in chloroform, fixed volume of saturated solution of antimony trichloride was used to treat and the formation of blue colour was measured using 21D spectrophotometer at the wavelength of $620 \mathrm{~nm}$. Blank value was also noted using the same procedure. By using the pure carotene standard curve was formed from which the carotene content of sample was calculated.

\section{Iodine value}

To find out the unsaturation level of fatty acid iodine value of the ghee samples were determined by Wij's method as described in SP: 18 (Part XI) - BIS, 1981 with few modification. Ghee sample of weight 0.40 to $0.45 \mathrm{~g}$ was taken in Iodine flask and the ghee sample was dissolved using $15 \mathrm{ml}$ of chloroform. Wiji's reagent was added to the iodine flask followed by completed mixing, the contents were kept undisturbed for one hour in dark. Then $20 \mathrm{ml}$ of $10 \%$ potassium iodide solution along with $150 \mathrm{ml}$ of distilled water were added to the flask. The above contents were titrated against $0.1 \mathrm{~N}$ sodium thiosulphate solution with starch solution as an indicator and also a blank value was taken with the same quantities of the reagents.

The iodine value was calculated as follows:

Iodine Value $=\frac{(B-S) N}{W} \times 12.69$

Where;

$\mathrm{B}=$ Volume of standard sodium thiosulphate solution for blank sample 
$\mathrm{S}=$ Volume of standard sodium thiosulphate solution for ghee sample

$\mathrm{N}=$ Normality of the standard sodium thiosulphate solution, and

$\mathrm{W}=$ Weight of the sample taken for the test

\section{Butyro-Refractometer (BR) reading at $40^{\circ} \mathrm{C}$}

Butyro-Refractometer reading, an index of purity of ghee was determined by the method described in SP:18 (1981). The butyrorefractometer was calibrated with the standard and the temperature of the was adjusted to $40.0 \pm 0.1^{\circ}$. Clean and the dry prism, on the lower prism of the refractometer, a drop of the molten ghee sample prisms was closed and held for 2 minutes. After adjusting the instrument and light to get the most distinct reading, the BR reading of the ghee was recorded.

\section{Reichert-Meissl (RM) and Polenske values}

Reichert-Meissl and Polenske values were determined as per the method described in SP:18 (1981). The Riechert-Meissl and Polenske value of all samples were determined to know the quality by the amount of soluble volatile fatty acids and insoluble volatile fatty soluble present in the ghee sample. Five gram of sample was weighed in Polenske flask and then saponified with 20.0 $\mathrm{g}$ of glycerol and $2.0 \mathrm{ml}$ of $50 \%(\mathrm{w} / \mathrm{w})$ sodium hydroxide solution on a direct flame then add distilled water with $50 \mathrm{ml}$ of sulphuric acid. Distillate of $110 \mathrm{ml}$ was collected within 20 minutes as soon as the flask connected with the distillation apparatus. The distillate was filtered through Whatman No.4 filter paper after cooled in a water bath and against $0.1 \mathrm{~N}$ sodium hydroxide solution with phenolphthalein as an indicator. Similarly, a blank test was also done by using all reagents without fat sample. From this, the RM value was calculated as follows:
$\mathrm{RM}=1.10(\mathrm{~T} 1-\mathrm{T} 2)$

$\mathrm{T} 1=$ Volume of $0.1 \mathrm{~N} \mathrm{NaOH}$ solution used for sample titration $(\mathrm{ml})$

$\mathrm{T} 2=$ Volume of $0.1 \mathrm{~N} \mathrm{NaOH}$ solution used for blank titration (ml)

For Polenske value (PV), the condenser, 25 $\mathrm{ml}$ cylinder, $110 \mathrm{ml}$ flask and the filter paper were washed with three successive washings of $15 \mathrm{ml}$ portions of cold water followed by neutralized alcohol.

The washings with neutralized alcohol were collected and then titrated against $0.1 \mathrm{~N}$ sodium hydroxide solution using phenolphthalein as an indicator.

Similarly, a blank was also done. From this, the Polenske value was calculated as follows:

Polenske Value $=\mathrm{T} 3-\mathrm{T} 4$

$\mathrm{T} 3=$ Volume $(\mathrm{ml})$ of $0.1 \mathrm{~N} \mathrm{NaOH}$ solution used for sample titration

$\mathrm{T} 4=$ Volume $(\mathrm{ml})$ of $0.1 \mathrm{~N} \mathrm{NaOH}$ solution used for blank titration

\section{Free fatty acids (FFA) in ghee}

Free fatty acids levels is the percentage by weight of free acid groups in the oil ghee samples were determined by the method as described in SP:18 (1981).

Filtered the melted fat using Whatman No. 1 and take $10 \mathrm{~g}$ of molten sample with $50 \mathrm{ml}$ to $100 \mathrm{ml}$ of freshly neutralized ethanol along with $1 \mathrm{ml}$ of phenolphthalein indicator. Titrate against alkali solution and after boiling for 5 minutes. The free fatty acids content was calculated as follows

Free fatty acids (as per cent, oleic acid) $=2.82$ $\mathrm{x}$ Titre value/ Weight

$\mathrm{T}=$ Volume in $\mathrm{ml}$ of $0.1 \mathrm{~N}$ Sodium hydroxide required for titration, and

$\mathrm{W}=$ Weight in $\mathrm{g}$ of ghee sample taken 


\section{Apparent Solidification Time (AST) Test}

The Apparent Solidification Time of the fat samples was determined by method described by Kumar et al., (2009b). It is recorded by studying the time taken by the melted fat samples to become apparently solidified at $18 \pm 0.2^{\circ} \mathrm{C}$. During the test only $3 \mathrm{~g}$ of the melted fat samples were placed in test tubes for 5 mins maintained at $60^{\circ} \mathrm{C}$. The test tubes were then kept in a refrigerated water bath maintained at $18 \pm 0.2^{\circ} \mathrm{C}$ The test tubes were observed till non-movement of fat samples on tilting the test tube which is the apparent solidification of fat and the time taken for the same was recorded as AST using a stop watch.

\section{Crystallization time test}

Crystallization test was done to analyze the average time required for the ghee sample to get to crystalized. The crystallization time test was followed as described by Panda and Bindal. Accurately $0.8 \mathrm{ml}$ of clear melted fat sample was transferred separately to the glass tube using pipette and added $2.5 \mathrm{ml}$ of the solvent mixture (acetone: benzene: 3.5:1). The contents in the glass tube were mixed thoroughly and placed in a water bath maintained at $20^{\circ} \mathrm{C} / 5 \mathrm{~min}$ for temperature equilibration and the time of onset of crystallization was noted down.

\section{Critical Temperature of Dissolution (CTD)}

The critical temperature of dissolution (CTD) of ghee samples was determined which is based by recording the temperature at which fat dissolved in a solvent mixture starts showing turbidity on cooling which is according to the method of Felman and Lepper (1950). Melted ghee sample of $2 \mathrm{ml}$ was taken in test tube along with $2 \mathrm{ml}$ of the solvent mixture consisting of 2 volumes of ethyl alcohol (95\%, v/v) and one volume of isoamyl alcohol (b.p. 128 to $132^{\circ} \mathrm{C}$ ). Using glycerol bath ghee samples was heating by continuous stirring until it got separated as two layer. Then the test tube was removed from the heating bath and stirring was continued until a definite turbidity appeared and at this stage the temperature was recorded as CTD.

\section{Complete Liquefaction Time (CLT) test}

The complete liquefaction time (CLT) of the fat samples is the time taken by the solidified fat samples to get melted completely at $45^{\circ} \mathrm{C}$ and it is estimated by the method described by Amit Kumar (2008).

Three gram of the completely melted fat sample was taken into a test tube was kept in an oven maintained at $60^{\circ} \mathrm{C}$ for a period of 5 minutes and then in a refrigerator $\left(6-8^{\circ} \mathrm{C}\right)$ for $45 \mathrm{~min}$ for solidification of the melted fat sample. After that the solidified sample was subjected to liquefaction process at $45^{\circ} \mathrm{C}$ for complete melting of the sample. The time for the sample to liquefy completely was recorded as CLT using stop watch.

\section{Results and Discussion}

\section{Nutritional composition of cow and buffalo ghee}

\section{Moisture}

Cow milk ghee and buffalo milk showed lower moisture content ie., $<0.5 \%$ that showed no significant difference. The lower moisture content in ghee apparently shows higher shelf life and keeping quality.

The present case revealed ghee was clarified at $115^{\circ} \mathrm{C}$ and which could be the prime reason for lower moisture content in all the ghee samples. The values were in accordance with the standard given by the FSSAI (2011). 


\section{Fat}

Fat is the primary energy source that imparts palatability to food, serves as a vehicle for fatsoluble vitamins $\mathrm{A}, \mathrm{D}, \mathrm{E}, \mathrm{K}$ and supplies essential fatty acids. The cow and buffalo milk ghee revealed similar higher fat content of $99.8 \pm 0.05(\mathrm{~g} / 100 \mathrm{~g})$ with no significant difference providing rich source of energy and abiding the limits of FSSAI (2011). The values were also in correlation with the results revealed by Parodi (2004).

\section{Protein}

Ghee is a scarce source of protein that's almost similar in cow and buffalo milk ghee. There was no significant change in the level of protein of the uthukuli ghee. The decreased heating time is due to the denaturation of all most all proteins. The Table 1 shows similar range of protein in cow and buffalo milk ghee compared to the standard ghee indicating the quality of prepared ghee.

\section{Tocopherol and Carotene}

The average tocopherol in cow and buffalo ghee were $45 \pm 0.22$ and $30 \pm 0.07 \mathrm{mg} / 100 \mathrm{~g}$, carotene content in cow and buffalo ghee $31 \pm 0.87$ and $35 \pm 0.63 \mathrm{IU} / 100 \mathrm{~g}$ respectively. The average tocopherol and carotene content in cow ghee revealed slightly higher indicating the physic-chemical characteristics of prepared ghee. The vitamin contents varied negligibly with the standards of FSSAI (2011) and also the values were similar to results found by Anon 2009, Pacher 2009.

\section{Cholesterol}

Cholesterol in its form is dispersed in the milk fat and present as an element of the complex membrane that forms the fat globules (Metin, 2012). After the analysis the cholesterol content of both ghee samples from cow and buffalo are $350 \pm 0.73$ and $312 \pm 0.83 \mathrm{mg} / 100 \mathrm{~g}$ respectively. Cow ghee has higher cholesterol level when compared to buffalo ghee. Cholesterol is determined to have good cholesterol (HDL) consumption of $10 \%$ ghee may increase triglyceride levels, but does not increase lipid peroxidation processes that are linked to a higher risk of cardiovascular disease (Kumar et al., 1999).

\section{Free fatty acid (\% Oleic acid)}

Free fatty acid content in ghee analysed to predict the oxidation stability and keeping quality. The FFA content of uthukuli ghee was found and expressed as percentage oleic acid. The value for free fatty acid (as oleic Acid) of samples of ghee is presented in Table 1 for both cow and buffalo. As per FSSAI and PFA standards the maximum permitted FFA level in ghee is 3\% oleic acid. The average values for free fatty acid of the cow and buffalo samples were $1.5 \%$ and $1.2 \%$, respectively, which were within the range.

\section{Physico-chemical properties of cow and buffalo ghee}

\section{Melting point}

Melting point of the prepared cow and buffalo ghee was $31.3 \pm 0.43$ and $33.5 \pm 0.61$ respectively. There was significant change in the melting point between the cow and buffalo ghee depicted that melting point is generally affected by type of breed, climatic conditions, method of preparation and chemical composition. The average change in melting point values reported in Table 2, are within the required standard value. The values were also in accordance with the result by Changade S.P et al., 2006.

\section{Reichert meissl (RM) value}

RM value of uthukuli cow and buffalo ghee samples ranged with an average of $28 \pm 0.24$ 
and $33 \pm 0.56$ respectively. Table 2 shows the standard RM value of Uthukuli ghee indicating the oxidation stability of ghee was within the standards of (FSSAI, 2011). The target value of RM value should not be less than 28 and more than 35 . The average value of samples was found to meet the required standard value. Arumughan and Narayanan (1982) reported that the average value for ghee (milk fat) samples about 22.6-34.5.

\section{Polenske value}

The polenske value in both cow and buffalo samples of ghee is shown in Table 2. The target value for polenske value should not be more than 1. Average Polenske values of 1.2 and 1.5 were reported for buffalo and cow ghee respectively by Lakshminarayana and Rama Murthy (1985). The average polenske value of cow and buffalo samples of Uthukuli ghee was found $0.5 \pm 0.04$ and $0.63 \pm 0.05$, it was found within the range.

\section{Saponification value}

Saponification value is the value which denotes the number of milligrams of $\mathrm{KOH}$ required for saponifying one gram of fat and it is the indirectly measure of the average molecular weight of fatty acid present. The saponification value of Uthukuli cow and buffalo ghee shown in Table 2 are $221 \pm 0.04$ and $227 \pm 0.12$ respectively which slightly varied from the finding of Singh and Gupta who determined the saponification value from cow and buffalo ghee about 234.12 \pm 2.45 .

\section{Iodine value}

The extent of unsaturation in milk fat can be detected by the Iodine value measurement. The average iodine value of Uthukuli cow and buffalo ghee samples are $32.2 \pm 0.91$ and 27.1 \pm 0.74 respectively. Similarly, Singh et al., (1946) reported iodine value ranging from 30.7 to 39.1 for ghee of Indian breeds of cows and 29.5 to 37.4 for ghee of buffaloes.

Table.1 Nutritional composition of cow and buffalo ghee

\begin{tabular}{|l|l|l|}
\hline Nutritional composition & Cow & Buffalo \\
\hline Moisture $(\%)$ & $<0.5$ & $<0.5$ \\
\hline Fat $(\mathrm{g} / 100 \mathrm{~g})$ & $99.8 \pm 0.05$ & $99.8 \pm 0.03$ \\
\hline Protein $(\mathrm{mg} / 100 \mathrm{~g})$ & $0.04 \pm 0.15$ & $0.04 \pm 0.15$ \\
\hline Tocopherol $(\mathrm{mg} / 100 \mathrm{~g})$ & $45 \pm 0.22$ & $30 \pm 0.07$ \\
\hline Carotene $(\mathrm{IU} / 100 \mathrm{~g})$ & $31 \pm 0.87$ & $35 \pm 0.63$ \\
\hline Cholesterol $(\mathrm{mg} / 100 \mathrm{~g})$ & $350 \pm 0.73$ & $312 \pm 0.83$ \\
\hline Free fatty acid $(\%$ oleic acid) & $1.5 \pm 0.11$ & $1.2 \pm 0.13$ \\
\hline
\end{tabular}

Table.2 Physico-chemical properties of cow and buffalo ghee

\begin{tabular}{|l|l|l|}
\hline Physico-chemical properties of ghee & Cow & Buffalo \\
\hline Melting point & $31.3 \pm 0.43$ & $33.5 \pm 0.61$ \\
\hline RM value & $28 \pm 0.24$ & $33 \pm 0.56$ \\
\hline Polenske value & $0.5 \pm 0.04$ & $0.63 \pm 0.05$ \\
\hline Saponification value & $221 \pm 0.04$ & $227 \pm 0.12$ \\
\hline Iodine value & $32.2 \pm 0.91$ & $27.1 \pm 0.74$ \\
\hline
\end{tabular}


Table.3 Physical properties of cow and buffalo ghee

\begin{tabular}{|l|l|l|}
\hline Physical properties & Cow & Buffalo \\
\hline Apparent Solidification test(AST)(min-sec) & $3-05 \pm 0.09$ & $2-71 \pm 0.05$ \\
\hline Complete liquification test(CLT)(min-sec) & $2-32 \pm 0.04$ & $2-37 \pm 0.11$ \\
\hline Crystallization time test (CTT) (min-sec) & $9-14 \pm 0.03$ & $7-48 \pm 0.08$ \\
\hline Butyro refractometer(BR) at $40^{\circ} \mathrm{C}$ & $41.8 \pm 0.03$ & $40.7 \pm 0.04$ \\
\hline Crtical temperature dissolution (CTD) & $53.3 \pm 0.15$ & $53.7 \pm 0.04$ \\
\hline
\end{tabular}

Physical properties of cow and buffalo ghee

\section{Apparent Solidification Test (AST) and Crystallization Time Test (CTT)}

AST - the time required for apparent solidification of cow and buffalo ghee was showed average value of minutes to seconds as 3-05 \pm 0.09 and 2-71 \pm 0.05 for samples respectively. Crystallization time test denotes the average time required to crystalize the ghee samples and results depicted in Table 3 are $9-14 \pm 0.03$ and 7-48 \pm 0.08 (min- sec) for Uthukuli cow and buffalo ghee respectively. Amit Kumar (2008) reported relevant results for cow and buffalo ghee collected for the whole year and checked bi-monthly. The crystallization time of ghee samples increased when the samples were adulterated with vegetable oils.

\section{Complete Liquification Test (CLT) and Critical Temperature Dissolution (CTD)}

Complete liquefaction test values shown in Table 2 are 2-32 \pm 0.04 and $2-37 \pm 0.11$ are falling within the limits of liquefying time of ghee at $44^{\circ} \mathrm{C}$.

The decrease or increase in CLT values caused only by the addition of adulterant oils/ fats to ghee depended upon the number of adulterants added. CTD values for the ghee samples are 53.3 \pm 0.15 and 53.7 \pm 0.04 for cow and buffalo ghee. It showed no significant difference within the sample and showed the limited range of values.

\section{Butyrorefractometer (BR) at $40^{\circ} \mathrm{C}$}

The average value of B.R reading was found to be $41.8 \pm 0.03$ and $40.7 \pm 0.04$ for cow and buffalo ghee respectively. The increased value of $\mathrm{BR}$ in ghee will be indicated by the lesser lower fatty acids, or by an increase either in higher saturated or unsaturated fatty acid (Rangappa and Achaya, 1974).

In conclusion, ghee, the clarified butter fat is one of the major dairy products in India. It has predominant role in Indian diet due to its good flavour, pleasant aroma as well as in the context of dietary guidelines, specially Uthukuli ghee is known for its extraordinary aroma.

Studies about this geographiclly relevant ghee are lacking scientific data or evidence. Hence, the above study conducted to shed new light on the basic physico-chemical properties of the ghee from both cow and buffalo origin present in the uthukuli region. To our knowledge this is the first kind of research to study about the uthukuli ghee which is one of the remarkable resource of south India.

This research work was initiated to study the physico-chemical properties of the ghee and all parameters were agreement within the range given by FSSAI (2011) and AGMARK (1981). This study will serve as the basic work to understand about the Uthukuli ghee and further more studies might be more advantageous. 


\section{References}

AGMARK.1981. Ghee Grading and Marking Rules, 1938 (as amended). Government of India, Ministry of Food and Agriculture, Department of Agriculture, New Delhi.

Amit Kumar. 2008. Detection of Adulterants in ghee. Ph.D. Thesis submitted to National Dairy Research Institute (Deemed University), Karnal, India.

Arumughan C. Narayanan KM (1982) Grain formation in Ghee (Butter fat) as Related to Structure of Triglycerides, J. food Sci. and Tech., 16: $242-247$.

BIS. 1981. Handbook of Food analysis, SP18, Part XI- Dairy Products. Bureau of Changade S.P., R.V. Tambat and R.R. Kanoje., (2006). Physical Proporties Of Ghee Prepared From High Acidic Milk- J. Dairying Foods\&H.S. 25(2): 101-104.

Felman, H.A. and Lepper, H.A. 1950. The critical temperature of dissolution as a rapid test to distinguish oleo margarine from butter. Agric. Chem. 33:492-499.

FSSAI Act (2006) and rules (2011). Akalank's food safety and standards Act, rules and regulation, Akalank publication, pp-40-43.

Indian Standards. Manak Bhavan, New Delhi. Kumar MV, Sambaiah K, Lokesh BR. Effect of dietary ghee - the anhydrous milk fat, on blood and liver lipids in rats. $J$ Nutr Biochem. 1999; 10: 96-104.

Metin, M. (2012). Süt Teknolojisi._Izmir: Ege University Press, 802pp.

non (2008) Buffalo milk Vs cow milk. [Internet document] URL http://www.indiadairy.com/info_buffa lo_milk_vs.html \#vitamin. Accessed $06 / 09 / 2008$.

non (2009) [Internet document] URL http://www.vegsoc.org/info/vegannutrition.html Accessed 22/11/2009.

Pacher G C (2009) Good Vitamin D Food Sources. [Internet document] URL http://ezinearticles.com/?GoodVitamin-D-Food-Sources\&id= 1384702. Accessed 22/11/2009.

Parodi, P.W. (2004). Milk fat in human nutrition. Aust. J. Dairy Technol., 59(1): 3-58.

Rangappa, K.S. and Achaya, K.T. 1974. Indian dairy products. Asia Publishing House, Bombay. pp 255-326.

Singh IP, Paul TM, Anantakrishnan CP, Rangaswamy MC (1946) Variations in the chemical constants of the butterfat of four breeds of India, Indian J. vet. Sci., 16: 170.

SP:18 (1981) Handbook of Food Analysis. Part XI Dairy Products. Manak Bhavan, New Delhi: Bureau of Indian Standards.

\section{How to cite this article:}

Bhavani Ramya, S., D. Baskaran, K. Vijayarani, R. Palanidorai and Ramasamy, D. 2019. A Study on Physico-Chemical Properties of Uthukuli Ghee. Int.J.Curr.Microbiol.App.Sci. 8(04): 2090-2099. doi: https://doi.org/10.20546/ijcmas.2019.804.246 